\title{
Evaluasi Sistem Laporan Keuangan Pada Kecamatan Sepatan Kabupaten Tangerang Menggunakan Metode Pieces
}

\author{
Trie Mayhera*1, Dwika Maulidia ${ }^{2}$, Siti Umi Khaifah ${ }^{3}$, Galih Seto $^{4}$, M. Rifal Alfarizi ${ }^{5}$ \\ 1,2,3,4,5Universitas Raharja; Jl. Jenderal Sudirman No.40, RT.002/RW.006, Cikokol, Kec. Tangerang, \\ Kota Tangerang, Banten 15117 \\ ${ }^{1,2,3}$ Sistem Informasi,${ }^{4,5}$ Sistem Komputer, Universitas Raharja, Tangerang \\ e-mail:*11trie.mayhera@ raharja.info, ${ }^{2}$ dwika.maulidia@ raharja.info, ${ }^{3}$ siti.umi@ raharja.info, \\ galih.seto@ raharja.info, $\underline{{ }^{4} \text { rifal.alfarizi@ raharja.info }}$
}

\begin{abstract}
Abstrak
Sistem laporan keuangan yang berjalan saat ini pada Kecamatan Sepatan Kabupaten Tangerang belum efektif dan efisien, karena prosesnya masih konvensional walaupun ada beberapa yang sudah menggunakan sistem. Untuk media penyimpanan pencatatan masih menggunakan menggunakan kertas, penggunaan media penyimpanan kertas rentan terhadap kehilangan data ataupun rusak. Tujuan dari penelitian ini yaitu untuk mengetahui cara pengolahan data laporan keuangan, mengusulkan sistem pengolahan data laporan keuangan yang efektif dan efisien, mengusulkan sistem pengolahan data laporan keuangan yang cepat dan akurat. Adapun permasalahan dalam penelitian ini yaitu sistem masih konvensional belum berjalan secara efektif dan efisien sehingga kinerja program menjadi lambat. Dari permasalahan tersebut, maka penulis mendapatkan alternatif pemecahan masalah bahwa perlu dilakukan pengkajian ulang sistem yang saat ini berjalan agar kinerja program tidak lambat dan perlu dikembangkan sistem yang ada agar prosedur menjadi terkomputerisasi.
\end{abstract}

Kata kunci-sistem, laporan keuangan, pengolahan data

\begin{abstract}
Financial reporting system in Sepatan District, Tangerang Regency, it is not yet effective and efficient, because the process is still conventional although there are some who are already using the system. For recording storage media still using paper, the use of paper storage media is susceptible to data loss or damage. The purpose of this research is to find out how to process financial report data, to propose an effective and efficient financial report data processing system, to propose a fast and accurate financial report data processing system. The problem in this study is that the conventional system has not been running effectively and efficiently so that program performance is slow. From these problems, the authors get an alternative solution to the problem that it is necessary to review the system that is currently running so that program performance is not slow and it is necessary to develop the existing system so that the procedure becomes computerized.
\end{abstract}

Keywords—system, financial reports, data processing

\section{PENDAHULUAN}

\section{Latar Belakang Masalah}

Di era sekarang, perkembangan teknologi sangat pesat. Begitu juga dengan sistem informasi akuntansi. Tujuan dari sistem informasi laporan keuangan adalah menyediakan informasi yang menyangkut posisi keuangan, kinerja, serta perubahan posisi keuangan suatu perusahaan atau instansi pemerintah yang bermanfaat bagi sejumlah besar pemakai dalam pengambilan keputusan.

Sesuai dengan Peraturan Pemerintah Nomor 71 Tahun 2010 tentang Standar Akuntansi Pemerintahan, Laporan keuangan terutama digunakan untuk mengetahui nilai sumber daya ekonomi yang dimanfaatkan untuk melaksanakan kegiatan operasional pemerintahan, menilai kondisi keuangan, mengevaluasi efektivitas dan efisiensi suatu entitas pelaporan, dan membantu menentukan ketaatannya terhadap peraturan perundang-undangan.

Kecamatan Sepatan adalah sebuah kecamatan yang terletak di kabupaten Tangerang. Dalam Kecamatan Sepatan Kabupaten Tangerang Laporan Keuangan yang berjalan saat ini sudah menggunakan komputer namun pengolahannya masih menggunakan sistem manual, dengan 
menggunakan Microsoft Excel belum menggunakan sistem informasi.

Dengan demikian adanya kebutuhan informasi yang makin lama semakin meningkat, maka diperlukan suatu sistem yang baik apabila akan memudahkan suatu proses. Penggunaan komputer sebagai alat laporan keuangan dapat meningkatkan kecepatan pekerja sehingga dicapai efisiensi tenaga dan keefektifan dalam waktu mengolah data.

\section{Telaah Literatur Dan Pengembangan Hipotesis \\ a. Pengertian sistem}

Dini Hamdini Mania (2017) mengatakan "Sistem adalah kumpulan dari elemen-elemen berupa data, jaringan kerja dari prosedur-prosedur yang saling berhubungan, sumber daya manusia, teknologi baik hardware maupun software yang saling berinteraksi sebagai satu kesatuan untuk mencapai tujuan/sasaran tertentu yang sama".

Rohmat Taufiq (2016) "sistem bisa berupa abstrak atau fisis. Sistem yang abstrak adalah susunan yang teratur dari gagasan gagasan atau konsep yang saling bergantung. Sedangkan sistem yang bersifat fisis adalah serangkaian unsur yang bekerja-sama untuk mencapai suatu tujuan."

Berdasarkan definisi di atas, maka dapat disimpulkan bahwa sistem adalah sekumpulan jaringan, elemen, objek yang saling bekerjasama dan berhubungan satu sama lain untuk mencapai suatu tujuan yang telah ditetapkan. Suatu sistem juga dapat terdiri dari beberapa subsistem, sebagai contoh: sistem akuntansi dapat terdiri dari subsistem akuntansi penjualan, subsistem akuntansi pembelian, penggajian dan sebagainya.

\section{b. Pengertian laporan keuangan}

Dalam bukunya V. Wiratna (2017:1), menurut Standar Akuntansi Keuangan (PSAK) (2015), laporan keuangan merupakan bagian dari proses pelaporan keuangan. Laporan keuangan yang lengkap biasanya meliputi neraca, laporan laba rugi, laporan perubahan posisi keuangan (yang dapat disajikan dalam berbagai cara misalnya sebagai laporan arus kas, atau laporan arus dana), catatan dan laporan lain serta materi penjelasan yang merupakan bagian integral dari laporan keuangan.

Secara umum laporan keuangan adalah catatan informasi keuangan suatu perusahaan pada periode akuntansi yang dapat digunakan untuk menggambarkan kinerja perusahaan tersebut.

Adapun tujuan dari pembuatan laporan keuangan sebagai berikut :

1. Memberikan informasi yang terpercaya

2. Memberikan informasi sumber kekayaan

3. Memungkinkan untuk menaksir potensi perusahaan dalam menghasilkan laba

4. Memberikan informasi yang diperlukan lainnya tentang perubahan aset dan kewajiban

5. Mengungkapkan informasi relevan lainnya yang dibutuhkan oleh para pemakai laporan

Dalam Standar Akuntansi Keuangan menjelaskan bahwa tujuan laporan keuangan adalah menyediakan informasi yang menyangkut posisi keuangan suatu perusahaan yang bermanfaat bagi sejumlah besar pemakai dalam pengambilan keputusan.

\section{c. Analisa PIECES}

Menurut Adi Supriatna (2017), PIECES framework adalah kerangka yang dipakai untuk mengklasifikasikan suatu problem, opportunities, dan directives yang terdapat pada bagian scope definition analisis dan perancangan sistem. Dengan kerangka ini, dapat dihasilkan halhal baru yang dapat menjadi pertimbangan dalam mengembangkan sistem. Dalam PIECES terdapat enam buah variabel yang digunakan untuk menganalisis sistem informasi, yaitu :

1. Kehandalan (Performance)

Keandalan suatu sistem merupakan variabel pertama dari PIECES dimana mempunyai peran penting untuk melihat sejauh mana dan seberapa handalkah suatu sistem informasi dalam berproses untuk menghasilkan tujuan yang diinginkan.

2. Informasi (Information)

Informasi merupakan komoditas krusial bagi pengguna akhir. Evaluasi terhadap kemampuan sistem informasi dalam menghasilkan informasi yang bermanfaat perlu dilakukan untuk menyikapi peluang dan menangani masalah yang muncul. Dalam hal ini meningkatkan kualitas informasi tidak dengan menambah jumlah informasi, karena terlalu banyak informasi malah akan menimbulkan masalah baru. 


\section{Ekonomi (Economic)}

Alasan ekonomi barangkali merupakan motivasi paling umum bagi suatu proyek. Pijakan bagi kebanyakan manajer adalah biaya atau rupiah. Persoalan ekonomis dan peluang berkaitan dengan masalah biaya.

4. Keamanan (Security)

Tugas-tugas bisnis perlu dimonitor dan dibetulkan jika ditemukan kinerja yang di bawah standar. Kontrol dipasang untuk meningkatkan kinerja sistem, mencegah, atau mendeteksi kesalahan sistem, menjamin keamanan data, dan persyaratan.

5. Efisiensi (Efficiency)

efisiensi menyangkut bagaimana menghasilkan output sebanyak-banyaknya dengan input yang sekecil mungkin.

Maka dilihat dari pendapat ahli di atas dapat disimpulkan bahwa analisa PIECES, merupakan analisis yang digunakan untuk melihat kelebihan ataupun kekurangan pada sistem yang ada dengan memfokuskan pada kinerja, informasi, ekonomi, pengendalian efisiensi dan pelayanan dimana hasil dari analisa ini dapat digunakan sebagai catatan perbaikan.

\section{METODE PENELITIAN}

Objek penelitian dilakukan di Kecamatan Sepatan, salah satu kecamatan yang terletak di Kabupaten Tangerang. Metode penelitian menggunakan deskriptif kuantitatif yaitu sebuah metode yang bertujuan untuk menggambarkan, meringkas, berbagai kondisi, berbagai situasi atau berbagai variabel yang timbul di masyarakat yang menjadi objek penelitian. Sumber data diperoleh dari wawancara langsung dengan pihak terkait yaitu divisi bagian keuangan pada kantor Kecamatan Sepatan Kabupaten Tangerang. Peneliti juga mengumpulkan informasi dan data dari berbagai sumber seperti buku, literature, catatan, serta laporan yang berkaitan dengan penelitian yang diteliti. Pada penelitian ini diperoleh informasi dari buku - buku referensi, jurnal ilmiah,literatur yang relevan objek yang diteliti, serta internet.

Analisa PIECES diperuntukan untuk menilai sistem yang berjalan dengan fokus analisanya berdsarkan Performance, Information, Economic, Control, Efficiency, dan Service. Tujuan diterapkannya analisis terhadap suatu sistem adalah untuk mengetahui alasan mengapa sistem tersebut diperlukan sehingga fungsi yang terdapat di dalam sistem tersebut bekerja secara optimal. Metode analisa yang digunakan adalah menggunakan metode PIECES yaitu :

1. Perfomance

Sistem yang berjalan saat ini masih menggunakan sistem manual. Sehingga mempersulit kinerja bendahara dalam pencatatan dan memperlambat proses pembuatan laporan keuangan

2. Information

Bendahara yang mencatat kejadian tiap transaksi keuangan secara periodic ke dalam buku kas secara manual. Karena proses yang manual tersebut, sehingga akan mempersulit penghitungan saldo dan kas.

3. Economy

Sistem yang berjalan saat ini dalam jangka panjang akan membutuhkan biaya dalam pembelian buku dan alat tulis.

4. Control

Proses pembuatan laporan keuangan sering terjadi kesalahan, sehingga berpotensi kecurangan dalam pembuatan laporan keuangan.

5. Efficiency

Dalam pembuatan laporan keuangan yang masih menggunakan buku dan memindahkan kembali ke dalam excel sehingga membutuhkan waktu yang lebih lama dan menjadi tidak efektif.

6. Service

Seringnya terjadi keterlambatan pencatatan dalam pembuatan laporan keuangan dikarenakan sistem yang masih bersifat manual.

\subsection{Prosedur yang berjalan}

\section{HASIL DAN PEMBAHASAN}

Berdasarkan hasil pengamatan, mekanisme dari laporan keuangan yang ada pada Kecamatan 
Sepatan saat ini yaitu:

1. Bendahara melakukan penerimaan keuangan.

2. Bendahara melakukakan pencatatatan pengeluaran berdasarkan bukti transaksi.

3. Bendahara merekap laporan keuangan.

4. Bendahara membuat surat pertanggungjawaban berdasarkan bukti transaksi.

5. Bendahara mengajukan surat pertanggungjawaban kepada Pelaksana Kegiatan untuk disesuaikan dengan kegiatan.

6. Jika sesuai, surat pertanggungjawaban diberikan kepada Penata Keuangan untuk usulan pembuatan laporan keuangan.

7. Penata keuangan akan membuat usulan pelaporan Surat Pertanggungjawaban untuk diberikan ke bendahara kembali.

8. Bendahara membuat laporan bulanan atau akhir tahun.

9. Setelah selesai laporan akan diberikan kepada Camat untuk disahkan.

10. Laporan yang telah disahkan di serahkan ke Bendahara Umum Daerah.

Diagram berikut menjelaskan proses yang terkait dengan actor dan sistemnya. Interaksi tersebut dapat digambarkan dengan use case diagram. Berikut ini adalah use case diagram proses laporan keuangan yang sedang berjalan pada Kecamatan Sepatan Kabupaten Tangerang.

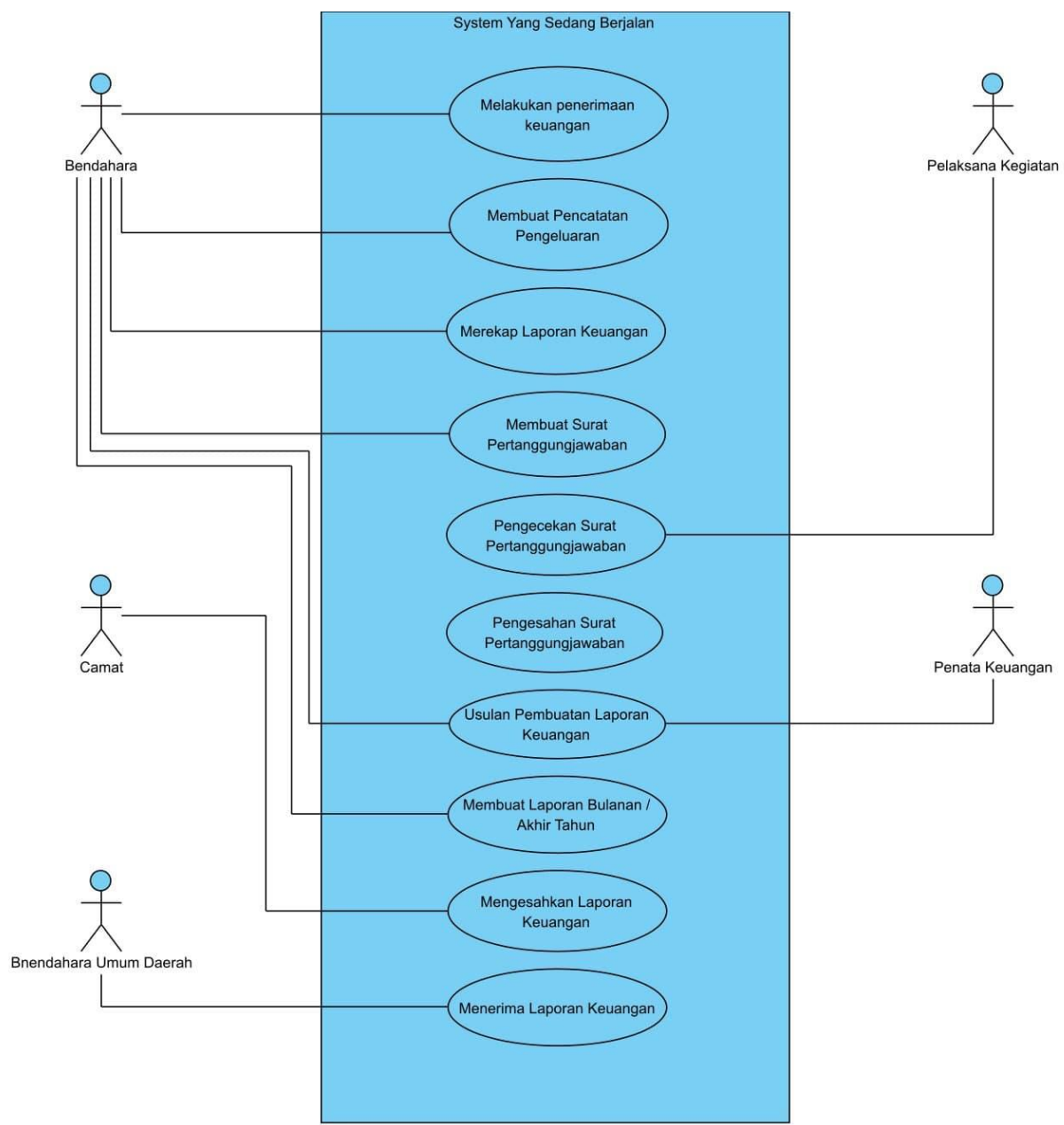

Gambar 1. Use Case Diagram

Berdasarkan use case diagram diatas, dapat diketahui, terdapat 1 (satu) sistem yang mencakup seluruh kegiatan, terdapat 5 (lima) actor dalam proses kegiatan yang berjalan, yaitu Bendahara, Camat, Pelaksana Kegiatan, Penata Keuangan, Bendahara Umum Daerah, dan terdapat 10 (sepuluh) case yang dilakukan oleh aktor-aktor tersebut. 


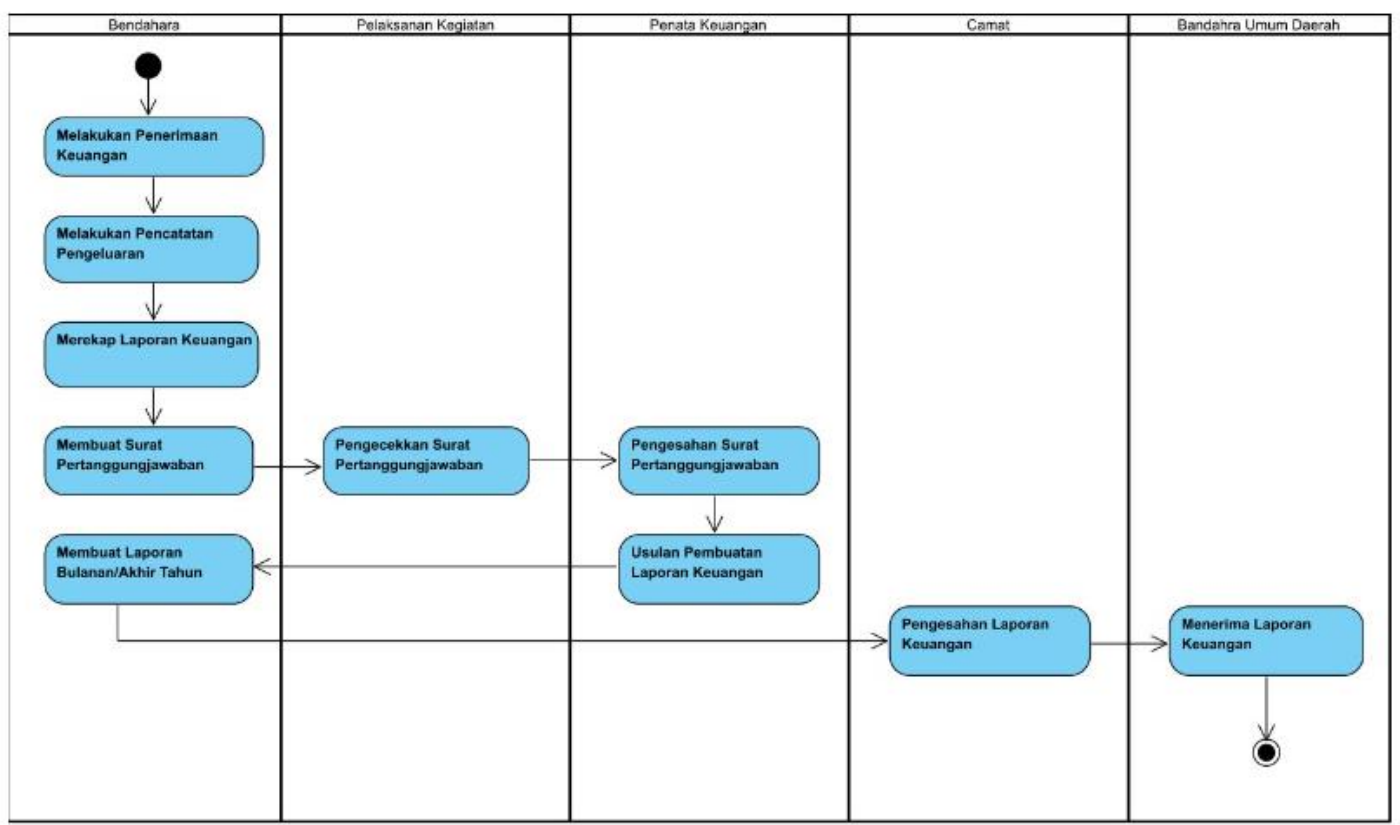

Gambar 2. Activity Diagram

Berdasarkan gambar Activity Diagram di atas terdapat: 1 initial node, objek yang mengawali kegiatan, 10 action, state dari sistem yang mencerminkan eksekusi dari suatu aksi, 1 final state, dan objek yang mengakhiri kegiatan.

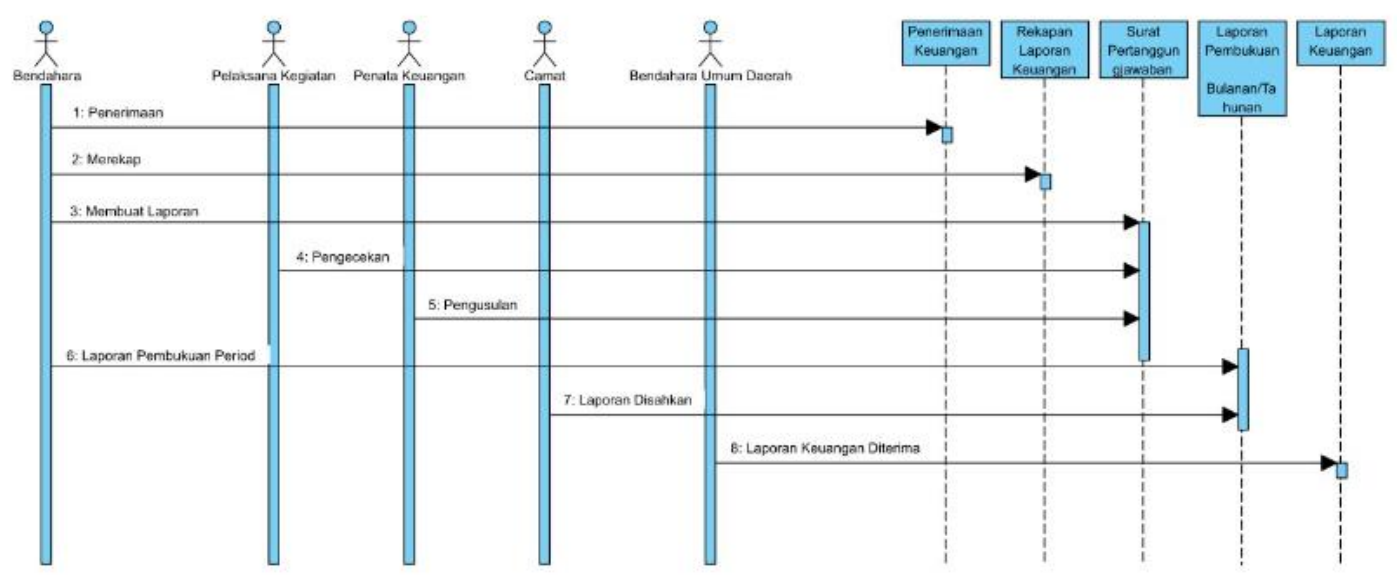

Gambar 3. Sequence Diagram

Berdasarkan gambar Sequence Diagram diatas yaitu : Terdapat 5 Actor terdiri dari : Bendahara, Pelaksana Kegiatan, Penata Keuangan, Camat, Bendahara Umum Daerah, Terdapat 5 Lifeline Terdiri dari : Penerimaan Keuangan, Rekapan Laporan Keuangan, Surat Pertanggungjawaban, Laporan Pembukuan, Laporan Keuangan, Terdapat 8 Massage memberikan informasi - informasi tentang gambaran aktivitas yang berlangsung pada proses kegiatan yang dilakukan oleh actor tersebut.

\subsection{Hasil Analisa Sistem}

\section{a. Metode Analisa PIECES}

Analisa PIECES adalah sebuah metode yang diperuntukan untuk menilai sistem yang berjalan dengan fokus analisanya berdasarkan Performance, Information, Economic, Control, Efficiency, dan Service. Tujuan diterapkannya analisis terhadap suatu sistem adalah untuk mengetahui alasan mengapa sistem tersebut diperlukan sehingga fungsi yang terdapat di dalam sistem tersebut bekerja secara optimal. Metode analisa yang digunakan penulis adalah menggunakan metode PIECES yaitu:

Tabel 1. Hasil Analisa

\begin{tabular}{|l|c|c|}
\hline No & Keterangan & Hasil Analisa \\
\hline
\end{tabular}




\begin{tabular}{|l|c|l|}
\hline 1 & $\begin{array}{c}\text { Performance } \\
\text { (kinerja) }\end{array}$ & $\begin{array}{l}\text { Sistem yang berjalan saat ini masih menggunakan sistem } \\
\text { manual. Sehingga mempersulit kinerja bendahara dalam } \\
\text { pencatatan dan memperlambat proses pembuatan laporan } \\
\text { keuangan. }\end{array}$ \\
\hline 2 & $\begin{array}{c}\text { Information } \\
\text { (informasi) }\end{array}$ & $\begin{array}{l}\text { Bendahara yang mencatat kejadian tiap transaksi keuangan } \\
\text { secara periodic ke dalam buku kas secara manual. Karena } \\
\text { proses yang manual tersebut, sehingga akan mempersulit } \\
\text { penghitungan saldo dan kas. }\end{array}$ \\
\hline 3 & $\begin{array}{c}\text { Economy } \\
\text { (biaya) }\end{array}$ & $\begin{array}{l}\text { Sistem yang berjalan saat ini dalam jangka panjang akan } \\
\text { membutuhkan biaya dalam pembelian buku dan alat tulis. }\end{array}$ \\
\hline 4 & $\begin{array}{c}\text { Control } \\
\text { (pengawasan) }\end{array}$ & $\begin{array}{l}\text { Proses pembuatan laporan keuangan sering terjadi kesalahan, } \\
\text { sehingga berpotensi kecurangan dalam pembuatan laporan } \\
\text { keuangan. }\end{array}$ \\
\hline 5 & $\begin{array}{c}\text { Efficiency } \\
\text { (efisien) }\end{array}$ & $\begin{array}{l}\text { Dalam pembuatan laporan keuangan yang masih menggunakan } \\
\text { buku dan memindahkan kembali ke dalam excel sehingga } \\
\text { membutuhkan waktu yang lebih lama dan menjadi tidak efektif. }\end{array}$ \\
\hline 6 & $\begin{array}{l}\text { Service } \\
\text { (pelayanan) }\end{array}$ & $\begin{array}{l}\text { Seringnya terjadi keterlambatan pencatatan dalam pembuatan } \\
\text { laporan keuangan dikarenakan sistem yang masih bersifat } \\
\text { manual. }\end{array}$ \\
\hline
\end{tabular}

Sumber : Data hasil analisa pada Laporan Keuangan Kecamatan Sepatan 2021

\section{KESIMPULAN}

Berdasarkan hasil analisa penelitian yang sudah diuraikan sebelumnya serta, berdasarkan hasil pengamatan mengenai Evaluasi Sistem Laporan Keuangan Pada Kecamatan Sepatan Kabupaten Tangerang, dapat diambil kesimpulan bahwa. Proses Laporan Keuangan pada Kecamatan Sepatan Kabupaten Tangerang sudah berjalan namun masih perlu dikembangkan dengan sistem yang lebih terkomputerisasi sehingga lebih cepat, efektif dan efisien. Sistem laporan keuangan yang berjalan saat ini kurang efektif, bendahara melakukan proses pencatatan, perhitungan, pengesahan, pertanggungjawaban dan pengeluaran dari bukti-bukti transaksi atau kejadian keuangan dilakukan saat akan membuat laporan keuangan dan mencatat setiap kejadian transaksi/kejadian keuangan secara periodik ke dalam buku kas umum secara konvensional. Sehingga mempersulit kinerja bendahara dalam mencari dokumen-dokumen tertulis yang sangat banyak dan membutuhkan proses pembuatan laporan keuangan yang cukup lama. Sistem yang berjalan pada Kecamatan Sepatan Kabupaten Tangerang masih semi komputerisasi, oleh karenanya peneliti mengusulkan sistem yang dapat digunakan oleh Kelurahan di wilayah Kecamatan Sepatan dalam proses pembuatan laporan keuangan yaitu menggunakan metode analisis PIECES. Sistem yang diusulkan diharapkan dapat mempermudah dalam proses permohonan administrasi dan laporan menjadi lebih efektif, efisien, cepat dan data lebih akurat.

\section{DAFTAR PUSTAKA}

[1] Maniah, \& Hamdini, D. (2017). Analisis dan Perancangan Sistem Informasi : Pembahasan Secara Praktis dengan Contoh Kasus. Yogyakarta: Deepublish.

[2] Sujarweni, V. (2017). Analisis Laporan Keuangan. Yogyakarta: Pustaka Baru Press.

[3] Supriyatna, A., \& Maria, V. (2017). Analisis Tingkat Kepuasan Pengguna dan Tingkat Kepentingan Penerapan Sistem Informasi DJP Online dengan Kerangka PIECES. Khazanah Informatika, Vol. 3 No. 2.

[4] Taufik, R. (2016). Rancang Bangun Sistem Pendukung Keputusan Hasil Nilai Siswa Naik dan Tidak Naik Berbasis JAVA Di SDN SEPATAN II. Jurnal Teknik, Vol 5 No. 2.

[5] Rahayu, Sri, Ai Ratna Sari, dan Tri Sendra Saputra. 2018. "Analisa Sistem Informasi Pengelolaan Keuangan Pada Upt Dinas Pendidikan Kecamatan Neglasari Kota Tangerang”. Jurnal SENSI Vol. 4 No. 1 - Februari 2018 ISSN: 2461-1409. Tangerang: Perguruan Tinggi Raharja. 
[6] O. Laoly and T. Limbong, "Visualisasi Pengumuman dan SOP Fakultas Ilmu Komputer Universitas Katolik Santo Thomas Medan berbasis Multimedia," MEANS (Media Informasi Analisa dan Sistem), vol. 3, no. 2, pp. 126-139, 2018, doi: 10.17605/JMEANS.V3I2.276.

[7] Azizah, Nur, Lina Yuliana dan Elsa Juliana. 2017. Rancang Bangun Sistem Informasi Penggajian Karyawan Harian Lepas Pada PT Flex Indonesia. Jurnal SENSI Vol.3 No.1 Februari 2017 ISSN : 2461-1409. 